\title{
Modified PBL Approaches in Nursing English Pedagogy and Their Impacts on Student's Achievement, Learning Strategies and Motivation
}

\author{
Weichieh Wayne Yu, \\ Department of Nursing, Chronic Diseases \& Health Promotion Research Center \\ Chang Gung University of Science \& Technology, Taiwan
}

Chunfu Charlie Lin,

Department of Applied Foreign Languages

National Formosa University, Yuling County, Taiwan

Jenny Wang,

Department of Applied Foreign Languages

National Formosa University, Yuling County, Taiwan

Mei-Hsin Ho

Department of Nursing, Chronic Diseases \& Health Promotion Research Center Chang Gung University of Science \& Technology, Taiwan

\begin{abstract}
Successful learning often lies in a defined philosophy of social factors that operate in the framework of individual experience. Constructivism, or constructivist learning has been a philosophical shift in the educational psychology. Problem-based learning (PBL) is a prime example of social constructivism. This quasi-experimental study investigated traditional lecture instruction, PBL, and blended problem-based learning (B-PBL) on students' academic achievement, motivation orientation, and use of learning strategies. Positive results for the field of education and B-PBL environments have indicated the need for changes in higher education course design. This study also indicates that a combination of factors for instructing course curricula may be extremely beneficial and essential to consider before designing a course. With findings from the study revealing significantly positive results from the BPBL group over the PBL group and the Traditional group, its impacts on academic achievement and self-regulation should not be overlooked.
\end{abstract}

Keywords: constructivist learning, problem-based learning (PBL), blended problembased learning (B-PBL), ICT, self-regulated learning, motivation orientation

\section{INTRODUCTION}

Problem-based learning (PBL) is social and experiential in nature, offers students an opportunity to learn how to learn, while engaging students in complex and diverse problem situations in a socially cognitive sharing environment. PBL is considered constructivist in nature for various reasons; one central reason is that it is student centered, in that it helps students make sense conceptually for themselves. PBL can be implemented in many different ways across many different domains. This type of learning is used to engage the learners into managing their environments with other team members in order to stimulate higher-order cognition. Instead of the curriculum being organized around the subject matter, the curriculum 
is structured around problem scenarios, with no predetermined set of right or wrong answers. Initially, students engage first in the involvement of circumstances rather than the concepts. Students learn within specific contexts, while most importantly, they are learning how to learn during a cyclical process where transitions help enhance students' understandings of that context [1]. Evenson \& Hmelo [2] suggest using a "Seven Jump" process when implementing PBL into the curriculum. The first step involves clarifying the unknown terms and concepts within the problem description. The second step requires students to define the problem. Third, students analyze the problem by brainstorming, activating prior knowledge. Fourth, students are to describe processes that may lie behind the problem scenario. Fifth, students formulate learning issues or questions for self-directed learning. Sixth, students research and find solutions independently through self-study. The seventh step in the process requires students to share their findings with others in the group and try to integrate the new knowledge into an explanation for the issues and possible solutions to problems. For this study, a modified "Seven Jump" PBL process was implemented. Modifications for Evensen and Hmelo's PBL suggestions were included the use of technology. Students integrated E-campus's information communication technology (ICT) features during the learning process. E-campus is an online course-management system that allows professors to post grades, information, and assignments. Instructors and students can also hold synchronous discussions via chat rooms. It is an interactive, web-based educational tool used to supplement or replace traditional classroom learning, transforming courses into blended-learning environments. Learners can assess to E-campus both on and off campus, and it is used for teaching and also learning support and development.

Very few studies have attempted to combine PBL and blended learning approaches, and those that have focused on presenting multimedia and communication platforms for students within the field of medicine/healthcare $[3,4]$. This study focused on supporting and enhancing the steps of PBL within the field of English education for pre- as well as in-service nurses. In addition, few studies have been dedicated to motivation's role in self-regulation in PBL and, unquestionably, there is a lack of studies that analyze the motivation levels within a blending problem-based learning (B-PBL) environment. Blended learning involves environments where information communication technology was used in addition to traditional methods of instruction during the learning process. Educators must see technology as a solution for more effective learning environments. Research needs to shift towards how we use technological media along with combined factors of course design rather than delivery mode [5]. In this study, the researcher focused on students' self-regulatory processes, including motivation and metacognitive strategies. More specifically, the researcher studied the impact of teaching via traditional face-to-face instruction, conventional PBL, and blended-problem-based learning (BPBL) on students' motivation orientation, use of learning strategies, and academic achievement.

\section{REVIEW OF LITERATURE}

Barrow [6] explains PBL to be an opportunity for students to solve an ill-structured problem where students will produce multiple thoughts and engage them in numerous explorations to solve the problem. Multiple domains with integrated information are involved within PBL rather than a student simply learning facts from one domain in lecture format. Small groups of learners connect prior knowledge, create their own learning issues or questions of interest about a problem scenario, share findings, and actively determine what information is relative to the problem. There is no basic right or wrong answer to problem scenarios, and the learning takes place in contexts, offering opportunity for people to learn how to learn and to connect learning with their own interests and motivations. 
Not only is the majority of the research on PBL centered on medical students and gifted education, the minimal amount of studies that exists outside of these two disciplines focus mainly on areas of flexible knowledge, effective problem solving, critical thinking skills, and self-directed learning skills. PBL has gained much interest of educators because of its potential for motivating students and transference of learning [7]. However, studies on the goals of PBL assisting in developing critical-thinking dispositions and motivation are underappreciated in the field of education.

\section{Self - Regulated Learning}

Zimmerman [8] defines self-regulated learning as a reaction of emotional planning adopted to achieve a personal goal. Using self-regulatory strategies effectively vastly affects a student's learning in many ways. Efficient self-regulated learners determine their learning objectives, monitor and evaluate their progress in the direction of meeting these objectives, and select the best strategy to maximize individual strengths while minimizing weakness [9]. Recent studies have demonstrated that a positive association exists between a student's academic achievement and his or her self-regulated learning skills [10-12]. In addition to improving their academic achievement, self-regulated learners can become aware of what they do and do not know. PBL can promote self-regulated learning, and self-regulated learning includes cognitive processes, such as critical-thinking dispositions and motivation orientation used during the PBL process.

According to ] Baumeister \& Vohs [13] a majority of researchers think more in cognitive rather than motivational terms. Motivation, especially its role in self-regulation has been underestimated. Motivation and willpower are important ingredients in the self-regulatory process. If motivation is high, it can substitute for a lower level of will power to complete tasks. Motivation can enable self-regulation to be successful.

\section{Motivation Orientation}

Garcia et al. [14] have defined nine types of learning strategies in relation to motivation orientation. These strategies have been divided into two categories: the first category is composed of cognitive and metacognitive strategies while the management of different resources comprises the other. Cognitive strategies are used to help an individual achieve a certain goal, while metacognitive strategies are used to ensure that the goal has been reached. Metacognitive strategies are those abilities to control or self-regulate one's own cognitive processes. Cognitive and metacognitive strategies include rehearsal, elaboration, organization, critical thinking, and metacognitive self-regulation. Rehearsal strategy, which is typically used for simple tasks, refers to the reciting of material or naming of parts to be learned. Used during the encoding processes, it is associated with the working memory. Elaboration strategy is often used to make connections between new information and prior knowledge and is associated with long-term memory. Creating analogies, paraphrasing, and summarizing are examples of this strategy. Organization strategy can simply be defined as making connections with the material to be learned. Prime examples of this strategy are illustrated by creating outlines and extracting the main ideas from a text. Critical thinking is demonstrated whenever students apply their previous knowledge to new situations in order to solve problems, make decisions, or evaluate. Finally, metacognitive self-regulation includes strategies, such as planning, monitoring, and regulating, to increase awareness or gain control over one's own cognition.

\section{Blended Learning}

Blended course design is combining aspects of a distance online course with the aspects of a traditional face-to-face classroom course. "Blended learning should be an integration of 
constructivist teaching methods with face-to-face learning in a classroom within an e-learning environment" [15]. Today's technologies can provide an opportunity of renovation for instructors where educators should see technology no longer as just a tool from which to present information in lecture format but rather see themselves as facilitators, considering technology as an avenue for the creation of learning experiences. Educators are urged to give much thought and reflection as to which way is the best to deliver content when designing a course [16].

Numerous researchers are reporting positive results utilizing PBL across disciplines [7,17-19], additional researchers are reporting positive benefits within blended-learning environments [20-25]. Higher education must reflect upon technology's role in providing more successful learning environments. It has been suggested that technology may be beneficial in adapting PBL for specific disciplines [7]. Larson \& Sung [5] sum it up best with the conclusion that research needs to shift towards how we use the technological medium along with combined factors of course design and student motivation rather than delivery mode. It is critical then, to focus studies on the types of environments provided for learning. It seems logical to investigate constructivist environments, such as implementing the PBL process to present course material, given the reports of positive results, but taking it a step further and investigating the combination of PBL within a blended-learning environment might reveal an even more successful learning environment. In addition, it seems applicable to study the above mentioned within the field of education with findings such as Walker \& Leary's [26] regarding the notion that teacher-education studies utilizing PBL are doing very well when compared to other disciplines. However, in order to create successfully combined learning environments, the issues that have emerged in the past regarding PBL and technology must be addressed.

\section{Research Questions}

The purpose of this study was to investigate the impact of students' motivation and academic achievement after learning within three different environments, which included instructing one group of students in a traditional lecture format, a second group of students within a PBL environment, and a third group of students within a blending PBL environment, allowing the students to use the information communication technology (ICT) features of E-campus during the PBL process. The following research questions guided this study regarding the impact of various teaching methods on students' academic achievement and self-regulatory processes:

1. Are there significant differences in academic achievement among students learning via three different teaching methodologies: problem-based learning (PBL), blended problem-based learning (B-PBL), and traditional face-to-face lecture classroom instruction?

2. Are there significant differences in motivation orientation among students learning via three different teaching methodologies: problem-based learning (PBL), blended problem-based learning (B-PBL), and traditional face-to-face lecture classroom instruction?

3. Are there significant differences in the use of learning strategies among students learning via three different teaching methodologies: problem-based learning (PBL), blended problem-based learning (B-PBL), and traditional face-to-face lecture classroom instruction?

\section{Population \& Participants}

\section{METHODOLOGY}

The accessible student population for the study was 150 undergraduate nursing major students enrolled in a regional campus of a science and technology institute in 2014. These 
students were mostly in their freshman and sophomore year, aging between 18 and 23 . They varied in their educational experience prior to entering the university. English for Nursing Purposes (ENP) is a required course which is offered year-round. Most students take this course during their first or second year of study. An average class size is around 50 students. The same instructor taught all three classes, however, utilized different instructional methodologies within each of the three sections. Students who took the class were encouraged to participate in the study. Voluntary participation was ensured both through explicit verbal and written explanations. The participants were told that they could withdraw from the study at any time and that their participation would in no way influence their academic standing in the class where the questionnaires were distributed. The subjects gave their consent by completing and returning the questionnaire. A total of 150 questionnaires were administered and 120 were returned, resulting in a response rate of $80 \%$.

\section{Instrumentation}

\section{Comprehensive Exam}

Students were administered one comprehensive course-content pretest and one comprehensive course-content posttest. The comprehensive exam contained 45 questions pertaining to content of the course for the semester. The questions were extracted from the course textbook.

\section{Reliability}

A split-halves method was used to test the reliability the comprehensive exam. The researchers asked 30 students who agreed to participate. The Spearman-Brown coefficient revealed .76, indicating a strong reliability and is suitable for evaluating individuals if averaged with several other scores of similar reliability. In addition, a Cronbach's alpha reliability test, an internal consistency reliability test, revealed a good reliability coefficient of .85 .

\section{Validity}

Chapter questions extracted from the concepts within the course textbook that have been created by experts in the field of English for Specific Purposes (ESP), and several long-term full-time professors and lecturers of the Department of Nursing. To establish the content validity of the items in the pretest/posttest comprehensive exam, experts in the fields of Applied English and Nursing were asked to help identify content necessary for assessment of academic achievement. They were also asked to validate the content of the instrument and review for things such as unclear instructions, confusing, ambiguous or repetitive items, and/or overly complex or difficult sentence structure. The researchers then revised the instrument based on the constructive feedback received from the reviewers.

\section{Motivational Strategies Learning Questionnaire}

The Motivated Strategies for Learning Questionnaire (MSLQ) was created to assess undergraduate students' motivational orientations and their uses of different learning strategies. The MSLQ is a self-report instrument, which consists of 31 motivation items (Part A) and 50 cognitive items (Part B), evaluating a student's beliefs about his ability to succeed in a course while the cognitive items assess the use of metacognitive and cognitive strategies. Figure 1 below illustrates the conceptual framework of MSLQ. The cognitive items also assess a student's resource management. Students rated themselves on a Likert scale $(1=$ not true of me, to 7 = very true of me). Students' value of task, expectancy for performance upon a task, and affective test anxiety are assessed through the instrument. The motivation subscales include intrinsic and extrinsic goal orientation, task value, control of learning beliefs, self- 
efficacy, and test anxiety. The learning strategies section contains four cognitive scales including (a) rehearsal, (b) elaboration, (c) organization, and (d) critical thinking.

The MSLQ is considered to be a reliable and valid means for assessing college students' motivation and use of learning strategies [27].

\section{Reliability}

For the MSLQ, internal consistency and reliability were shown to be sound according to the coefficient alphas for the motivational scales and learning strategy scales. Task value beliefs concerning students' ratings about how interesting, useful, and important the course material is to them had a very high alpha of .90. Students' judgments of self-efficacy for learning had a high alpha of .93. Test anxiety and intrinsic goal orientation subscales showed internally consistent estimates with .80 and .74. Learning strategies showed alphas averaging above .70. Yielding the lowest results, extrinsic goal orientation and control of learning beliefs yielded coefficient alphas of approximately .65, while help-seeking indicated the lowest alpha of below $.60[28]$.

\section{Validity}

VI [29] was used to estimate and test the models. Thirty-one motivation items were tested to see how well they fit six factors: intrinsic goal orientation, extrinsic goal orientation, task value, control of learning beliefs, self-efficacy for learning and performance, and test anxiety. Fifty cognitive/metacognitive strategy items were tested to see how well they fit nine factors: rehearsal, elaboration, organization, critical thinking, metacognitive self-regulation, time and study environment management, effort regulation, peer learning, and help seeking. Goodness of fit tests indicated that they are quite reasonable values, given the fact that they are spanning a broad range of courses and subject domains. Overall the models show sound structures with a claim for factor validity for the MSLQ scales. Chi-square goodness-of-fit test is used to see if the sample comes from the population with the claimed distribution. The Goodness-of-fit test for the motivation six latent factors resulted in .77, with the largest modification index provided by Liseral VI at 50.2. The very same test for the cognitive nine latent factors was .78, with the largest modification index provided by Lisrel VI at 91.59 [30].

\section{Traditional Face-to-Face Procedures}

Pretests of comprehensive exam and the Motivational Strategies Learning Questionnaire (MSLQ) were administered during week two of this 18-week course. The traditional face-toface format of instruction consisted of the instructor lecturing while covering chapters one through eight of the course textbook. The instructor lectured, utilizing PowerPoint presentations in addition to distributing PowerPoint handouts to the students during each session. Regarding assessment, during each chapter section, there were some small group (non-PBL) work activities related to the chapters along with outside homework assignments of reading the text chapters and journal-entry review assignments. Each review assignment required the students to read additional information beyond the text, yet related to the chapters. Throughout the semester, students completed a total of four (4) quizzes, each covering two lessons in the textbook. During week seventeenth, students were administered the MSLQ questionnaire posttest. During the week of the finals, a comprehensive exam administered covering chapters one through eight of the text, which was the posttest for this study. Students were asked not to study for this final exam, as the result would not count towards their final grade. 


\section{PBL Procedures}

The PBL format of instruction consisted of the same instructor taking on the role of the facilitator. A comprehensive course-content pretest and a MSLQ pretest were also administered during week two. Students were divided into groups of five. Each group was assigned the same problem over which they researched and collaboratively discussed. The students worked on problem-based assignments for two to three class periods, depending upon the length of the chapter.

Students completed part of the problem-based process in the computer lab. In addition, there was one class period dedicated to teacher-led PowerPoint whole-group discussion relative to each chapter, following total completion of the problem-based assignment corresponding to the chapter. According to Schwartz \& Bransford [17], students solving problems before the lecture performed better on problem-solving tasks than those students who just solved the problems.

A modified "Seven Jump" for PBL was used for this study. Students received problems each week relative to the chapter of course textbook. Modified "Seven Jump" process required students to complete a 6 step PBL process. First, the students defined the problem. Secondly, they brainstormed ideas and solutions to problems in order to activate prior knowledge. Third, they developed learning issues or questions about which they would like to gain new knowledge. Fourth, they researched individually to primarily find a solution to the problem. During the research stage, students were provided with handouts of links to look up on the World Wide Web. The 5th step involved group reconvening, in order for discussion of findings. All five steps were completed during two-hour class period. The following class period was scheduled for whole group discussion. Between the PBL assignment and whole group discussion, students completed 6th step which required participants to individually write a one-page journal entry explaining how their group decided to solve the assigned problem, during their in-class collaboration step of the PBL process. Students submitted a one-page reflection at the beginning of the following class discussion period. These procedures were consistently followed for each of the eight problems, relative to textbook chapters, presented over the 18-week semester. Table 1 below illustrates sample English for Specific Purposes (ESP) class format of a conventional PBL. In week seventeenth, students were administered the MSLQ questionnaire posttest. During final's week, students were again administered a comprehensive course-content posttest covering chapters one through eight of text.

Table 1. Sample Class Using A Conventional PBL Format on Oncology unit

\begin{tabular}{|c|c|c|}
\hline PBL Step & $\begin{array}{l}\text { Class Period/ } \\
\text { Place/ Duration }\end{array}$ & Procedures \\
\hline & Before Class & $\begin{array}{l}\text { 1. Students will read a medical column/admission } \\
\text { note relative to the chapter/unit. } \\
\text { 2. Problems provided to students before class, i.e. } \\
\text { - What is the Oncology Unit? } \\
\text { - What are different types of cancer? } \\
\text { - What are the stages of tumor development? } \\
\text { - How is cancer treated? } \\
\text { - What are some possible side effects of } \\
\text { Chemotherapy? Etc. }\end{array}$ \\
\hline $\begin{array}{c}1 \\
\text { (Define) }\end{array}$ & $\begin{array}{c}\text { Class } 1 / \text { Classroom \& } \\
\text { Lab./ } 2 \text { hrs }\end{array}$ & $\begin{array}{l}\text { 1. Watch Video Clips of (Hawthorne and/or ER) } \\
\text { 2. Students define the problems received prior to } \\
\text { class }\end{array}$ \\
\hline
\end{tabular}




\begin{tabular}{|c|c|c|}
\hline $\begin{array}{c}2 \\
\text { (Brainstorm) }\end{array}$ & & $\begin{array}{l}\text { Students brainstorm ideas and solutions to activate } \\
\text { their knowledge. }\end{array}$ \\
\hline $\begin{array}{c}3 \\
\text { (Develop) }\end{array}$ & & $\begin{array}{l}\text { Students develop learning issues/questions about } \\
\text { which they'd like to gain knowledge, i.e. } \\
\text { - Conduct an admission interview } \\
\text { - Communicate with the patients during } \\
\text { - hospitalization } \\
\text { - Talking about side effects after treatment } \\
\text { - Lischarge teaching } \\
\end{array}$ \\
\hline $\begin{array}{c}4 \\
\text { (Research) } \\
\end{array}$ & & $\begin{array}{l}\text { Students research individually to find solutions to } \\
\text { the problem(s). }\end{array}$ \\
\hline $\begin{array}{c}5 \\
\text { (Reconvene) }\end{array}$ & & $\begin{array}{l}\text { Group members reconvene to discussion their } \\
\text { findings }\end{array}$ \\
\hline $\begin{array}{c}6 \\
\text { (Discuss) }\end{array}$ & $\begin{array}{l}\text { Class 2/ Classroom/ } \\
2 \text { hrs }\end{array}$ & $\begin{array}{l}\text { Whole group discussion, including completion of a } \\
\text { collaborative one-page reflection. }\end{array}$ \\
\hline
\end{tabular}

\section{Blended-Problem-Based Learning (B-PBL) Procedures}

Pretests of comprehensive course-content and MSLQ were administered in week two. The BPBL environment required the students to follow the same PBL steps; however, the approach was diverse. The main difference for the B-PBL process was the flexible nature of technology, allowing for more time and a break between steps. The theme of PBL flexibility issues reported from the research [31,32] was taken into account with the notion that students indicated needing more time for thorough completion of the PBL process. The students did not complete all five steps of the PBL process in one class period as described above in PBL group. Rather, the B-PBL students were allowed the opportunity to complete steps 1-4 only at their own pace during the entire two-hour class session, depending upon the length of time each group needed to work. Step 5 of PBL process was separated from the other steps and completed outside of class within E-campus's chat room. This type of blended teaching methodology offered the groups an opportunity for more time to complete the PBL process based upon how their group operated and completed tasks, lowering frustration levels.

In addition to using the chat room feature of E-campus, students used supplemental information communication features of E-campus. They used the discussion forum to post questions and times for students to meet regarding their PBL assignments, allowing for alternative communication outside the classroom. Also, during the B-PBL process, students used the technological convenience of E-campus's information-communication features to download PowerPoint presentations, PBL assignment sheets, and research links. During the research stage, students were provided with links through E-campus's posting features, which served a purpose to save time during the in-class step 4. After completing the chat session step 5 from the students' computers at home, the students were asked to write a collaborative group reflection as step 6 as their homework assignment. Students were given a MSLQ posttest and a final comprehensive test in their designated time.

\section{DATA ANALYSIS}

The statistical data analysis used for the comprehensive exam data scores were parametric statistical techniques. The dependent variables for this study were academic achievement, motivation orientation, use of learning strategies, and critical-thinking dispositions. The independent variables were three different instructional modalities, including traditional faceto-face lecture, PBL, and B- PBL. In order to test for statistical differences an ANOVA was used 
Yu, W. W., Lin, C. C., Wang, J., \& Ho, Mei-Hsin (2014). Modified PBL Approaches in Nursing English Pedagogy and Their Impacts on Student's Achievement, Learning Strategies and Motivation. Advances in Social Sciences Research Journal, 1(5),198-212

on the pretest/Posttest comprehensive exam for the three groups of students being taught via different teaching methodologies. A Multivariant analysis (MANOVA) was used on the pretest/posttest subcategory scores relative to self-regulation. MANOVA was initially run to test for significant differences at the pretest for the MSLQ. When significant differences were noted among the groups at the pretest, the researcher must consider the Analysis of Covariance (ANCOVA), given that the sample population was not randomly selected. Statistical analysis was performed using the most current version of Statistical Package for Social Sciences (SPSS) for Windows.

\section{RESULTS}

Research question one asked: "Are there significant differences in academic achievement among students learning via three different teaching methodologies: problem-based learning (PBL), blended problem-based learning (B-PBL), and traditional face-to-face lecture classroom instruction?"

Table 2 shows the descriptive statistics for students' academic achievement scores on the comprehensive exam. The B-PBL group had the highest mean average of 79.13 , while the traditional group had the lowest mean average score of 65.34 on the posttest.

Table 2. Descriptive Statistics Comprehensive Exam Pretest/Posttest Scores for Academic Achievement

\begin{tabular}{lcccc}
\hline & Group & Mean & SD & n \\
\hline Pretest Academic Achievement & PBL & 21.17 & 8.30 & 40 \\
& B-PBL & 25.48 & 8.68 & 39 \\
& Traditional & 24.10 & 8.51 & 41 \\
Posttest Academic Achievement & PBL & 70.37 & 10.71 & 40 \\
& B-PBL & 79.13 & 12.50 & 39 \\
& Traditional & 65.34 & 11.62 & 41 \\
\hline
\end{tabular}

No statistically significant differences were found by the ANOVA test on students' pretest scores. However at the end of the study, based upon posttest scores, the groups were significantly different, $\mathrm{F}=10.83, \mathrm{p}<.05$.

Table 3. ANOVA for Comprehensive Exam Pretest/Posttest Scores for Academic Achievement

\begin{tabular}{ccccccc}
\hline & & $\begin{array}{c}\text { Sum of } \\
\text { Squares }\end{array}$ & f & Mean Square & F & Sig. \\
\hline \multirow{2}{*}{ Pretest } & Between Groups & 295.00 & 2 & 147.50 & 2.042 & .14 \\
& Within Groups & 6284.59 & 117 & 72.23 & & \\
Posttest & Between Group & 2935.09 & 2 & 1467.54 & 10.82 & $.00 *$ \\
& Within Groups & 11795.00 & 117 & 135.57 & & \\
\hline
\end{tabular}

A post hoc Tukey HSD multiple comparison test was necessary to determine group differences after significant differences in scores were revealed. Table 4 illustrates the data for the Post Hoc Tukey HSD individual between group comparisons at the posttest for academic achievement. There was a significant difference between the B-PBL group and the PBL group at the posttest with $\mathrm{p}<.05$. The B-PBL teaching methodology was shown to have a significant impact on the students' academic achievement posttest scores. In addition, the B-PBL group had significantly higher posttest scores than that of the PBL and the traditional groups. 
Table 4. Tukey HSD Post Hoc - Individual Comparisons between Groups at Posttest for Different Teaching Methodologies Impact on Academic Achievement

\begin{tabular}{ccccc}
\hline \multirow{2}{*}{ Time } & Group(I) & Group(II) & $\begin{array}{l}\text { Mean } \\
\text { Difference }\end{array}$ & \multicolumn{1}{c}{ Sig. } \\
\hline \multirow{2}{*}{ Posttest } & B-PBL & PBL & 8.76 & $.01^{*}$ \\
& PBL & Traditional & 5.02 & .23 \\
& B-PBL & Traditional & 13.78 & $.00^{*}$ \\
\hline
\end{tabular}

Research question two asked: "Are there significant differences in motivation orientation among students learning via three different teaching methodologies: problem based learning (PBL), blended problem-based learning (B-PBL), and traditional face-to-face lecture classroom instruction?"

As illustrated in Table 5 Roy's Largest Root multi-variant test (MANOVA) revealed that the motivation orientation pretest mean scores were not significantly different with $F=2.99, p>$ .05 .

Table 5. Multivariate tests - MANOVA for Motivation Orientation category at Pretest / Posttest

\begin{tabular}{llllclc} 
& & Value & F & Hypothesis df & Error df & Sig. \\
\hline Pretest & Roy's Largest Root & .20 & 2.99 & 6.00 & 89.00 & .060 \\
Posttest & Pillai's Trace & .29 & 2.31 & 12.00 & 164.00 & .060 \\
\hline
\end{tabular}

At the posttest, table 6 shows the test of between subject effects revealed that the subcategory of test anxiety was significantly different among the groups $(F=7.82, \mathrm{p}=<.05)$. There were no significant differences among the groups' mean scores at the MSLQ posttest for the subcategories of control of learning beliefs, intrinsic and extrinsic goal orientation, selfefficacy, and task value.

Table 6. Test of Between Subjects ANOVA for MSLQ Posttest on all Six Subcategories of Motivation Orientation

\begin{tabular}{llccccc}
\hline Source & Dependent Variable & $\begin{array}{c}\text { Type III Sum of } \\
\text { Squares }\end{array}$ & df & $\begin{array}{c}\text { Mean } \\
\text { Square }\end{array}$ & F & Sig. \\
\hline Groups & $\begin{array}{l}\text { Control of Learning } \\
\text { Beliefs }\end{array}$ & 2.98 & 2 & 1.49 & 2.07 & .13 \\
& $\begin{array}{l}\text { Extrinsic Goal } \\
\text { Orientation }\end{array}$ & 5.57 & 2 & 2.79 & 2.56 & .08 \\
& $\begin{array}{l}\text { Intrinsic Goal } \\
\text { Orientation }\end{array}$ & 1.01 & 2 & .51 & & \\
& Self-Efficacy & & & & .65 & .52 \\
& $\begin{array}{l}\text { Task Value } \\
\text { Test Anxiety }\end{array}$ & 2.02 & 2 & 1.01 & 1.44 & .24 \\
& .11 & 2 & .06 & .05 & .95 \\
& 31.65 & 2 & 15.82 & 7.82 & $.00^{*}$ \\
\hline
\end{tabular}

A Tukey HSD post hoc test showed a statistically significant mean difference $(p<.05)$ existed between the B-PBL group and PBL group (as shown in Table 7), indicating that the B-PBL group's scores were significantly lower than the PBL group's scores. Therefore, the B-PBL group has significantly lower levels negative disruptive thoughts during test performance. A significant difference was also found between the traditional group and the PBL group ( $\mathrm{p}<.05)$, suggesting that the traditional group's scores were significantly lower than the PBL group's scores. Thus, the traditional group had significantly lower levels of negative disruptive thoughts during test performance. 
Yu, W. W., Lin, C. C., Wang, J., \& Ho, Mei-Hsin (2014). Modified PBL Approaches in Nursing English Pedagogy and Their Impacts on Student's Achievement, Learning Strategies and Motivation. Advances in Social Sciences Research Journal, 1(5),198-212

Table 7. Tukey Post Hoc - Individual Comparisons between Groups at MSLQ Motivation Orientation Posttest Test Anxiety

\begin{tabular}{ccccc}
\hline \multirow{2}{*}{ Time } & \multirow{2}{*}{ Group (I) } & \multirow{2}{*}{ Group (II) } & $\begin{array}{l}\text { Mean } \\
\text { Difference }\end{array}$ & \multicolumn{1}{l}{ Sig. } \\
\hline Posttest & B-PBL & PBL & -1.24 & $.00^{*}$ \\
& PBL & Traditional & 1.28 & $.00^{*}$ \\
& B-PBL & Traditional & .04 & .99 \\
\hline
\end{tabular}

Research question three asked: "Are there significant differences in the use of learning strategies among students learning via three different teaching methodologies: problem-based learning (PBL), blended problem-based learning (B-PBL), and traditional face-to-face lecture classroom instruction?"

Based on pretest scores, the MANOVA results for the MSLQ revealed no preexisting differences among groups with respect to students' use of learning. With regard to posttest scores, a oneway ANOVA revealed a significant difference among the groups for critical thinking and help seeking for the use of learning strategies category, with $\mathrm{F}=3.45, \mathrm{p}<.05$. A post hoc Tukey HD test (Table 8) showed a significant difference existed between the PBL group and B- PBL group. In addition, a significant difference occurred between the B-PBL and the traditional group for critical thinking skills.

Table 8 - Tukey Post Hoc - Individual Comparisons between Groups at MSLQ Use of Learning Strategies

\begin{tabular}{cclcc}
\hline Time & Group (I) & Group (II) & $\begin{array}{c}\text { Mean } \\
\text { Difference }\end{array}$ & Sig. \\
\hline Posttest & B-PBL & PBL & .77 & $.02^{*}$ \\
& PBL & Traditional & -.15 & .65 \\
& B-PBL & Traditional & .62 & $.05^{*}$ \\
\hline
\end{tabular}

DISCUSSION \& CONCLUSIONS

With regard to the comprehensive exam, the findings showed that there were statistically significant differences among academic achievement scores for the traditional, PBL, and B-PBL groups. Interestingly, the study revealed that the B-PBL group had a statistically significant difference in tests scores from pretest to posttest than the Traditional group and the PBL group. The B-PBL group's academic achievement posttest mean scores were significantly higher than the PBL mean scores and the Traditional mean scores.

For the MSLQ's motivation orientation category, the findings showed that at the pretest, only the self-efficacy for performance and learning subscale showed significant differences. It may have been that the groups were similar at the pretest on control of learning beliefs, extrinsic motivation, intrinsic motivation, task value, and test anxiety. At the posttest, the findings for motivation orientation category revealed statistically significant lower levels of test anxiety for the B-PBL group than the PBL and the Traditional groups. As far as the MSLQ's use of learning strategies category is concerned, the findings showed no significant differences among the groups at the pretest on all subscales. At the posttest, the findings for the MSLQ's use of learning strategies showed a statistically significant difference among groups for the subscale categories of critical thinking skills and help seeking. The B-PBL groups critical thinking skills subscale scores were significantly higher than the PBL group and the Traditional group.

One of the most notable findings from this study, resulting from the MSLQ subscale, was test anxiety scores measuring significantly lower in both the B-PBL group and Traditional group when compared to the PBL group. The B-PBL group and the Traditional group had significantly 
lower scores for test anxiety. Having lower levels of test anxiety means that students in the BPBL group and the Traditional group had significantly lower levels of negative and disruptive thoughts during test taking. "Test anxiety has been found to be negatively related to expectancies as well as academic performance. Cognitive concern and preoccupation with performance have been found to be the greatest sources of performance decrement." [33].

Another notable finding from this study, regarding the use of learning strategies, revealed that the students in the B-PBL group had significantly higher critical thinking skill scores than the PBL group and the Traditional group. There was no significant difference in critical thinking between the Traditional and the PBL group. Relative to theory, a possible explanation for the critical thinking skills findings, according to Baumeister \& Vohs [34], are that students have a limited stock of resources, such as decision making, for example. The PBL process is a very time consuming and a tedious process that can be overwhelming and can deplete a student's cognitive resources before the entire process is complete, raising anxiety if forced to complete all steps thoroughly in one class period. These findings could indicate that using E-campus discussion and chat room features as part of the PBL process allowed the students a longer amount of time for longer in-depth discussions outside of class, with a break in between PBL steps. Longer in-depth discussions allows more time for developing critical thinking skills. In this study, the PBL learning process did give the learner much control over their own learning and demanded for reflective thinking. Means et al. [35] suggested that several researchers have found that when learners are exposed to opportunities in which they have more control over their learning environments, the results have revealed larger gains over teacher-lead expository instruction [36-38]. The results of the study echoed that of the previous researchers by showing that within the B-PBL environment, students had much more control over their own learning during the entire PBL face-to face-and online.

The findings of the study also add to the literature that the B-PBL group scored significantly higher than the PBL group for use of learning strategies in the subcategory of help seeking. Research indicates that peer help, peer tutoring, and individual teacher assistance facilitate student achievement [39]. Karabenick [39] further explains using technology to communicate diminishes the potential of feelings of embarrassment created while asking questions in person. Kitsanta \& Chow [40] concluded that overall, students preferred using electronic means to seek help from instructors and classmates. Shyness, language and learning styles barriers are removed. These statements are supported by the current study, because the B-PBL groups had significantly higher help seeking scores and significantly higher academic achievement over the PBL group that did not use technology through which to communicate. Researchers imply that web enhanced and distance learning environments, more than traditional learning environments, facilitate help seeking because of reduced threat and effort, higher quality, convenience, and assisting with requirements $[40,41]$. The findings from the current study also support these researchers' conclusions in regards to online technology and web enhanced environments assisting students with help seeking. PBL environments fosters a need for student support; however, in the PBL non technology group, there were no communication tools offered that allowed students the opportunity to seek support from other members as did the B-PBL course. Also, perhaps frustrations, anxieties, and time constraints distracted students to the point of creating the inability for them to have the opportunity to effectively seek help from other students. In the traditional classroom setting non PBL group work did occur, and without time constraints, along with a familiar pattern of instruction, could have caused the students to feel more at ease to seek help during group work, possibly explaining why there was no significant difference in help seeking between the B-PBL group and the Traditional group. 


\section{RECOMMENDATIONS FOR FUTURE STUDY}

Basing on the results obtained from the study, the researchers made the following recommendation for future study: First recommendation would be to obtain and analyze data from a larger population accomplished through a longitudinal study. Another recommendation would be to conduct a qualitative study on student's views regarding the usage of E-campus as part of the PBL process. For instance, students could be asked about their feelings regarding group work pros and cons during E-campus chats. Moreover, how students feel about the B-PBL methodologies of instruction could give educators some insight into why certain motivation orientations and use of learning strategies are or are not significantly enhanced in the B-PBL group. Finally, a recommended study would be to compare B-PBL environments and PBL environments and the effects on students' collaborative skills. PBL learning is a meaning making process that can help develop intracommunity trust. Investigating collaborative skills within these two types of environments can help researchers better understand how students are transformed from strangers into communities.

\section{ACKNOWLEDGMENTS}

This project and publication were funded by Chang Gung Medical Research Program (CMRPF6D0011). Wei-Chieh Wayne Yu, from the Chang Gung University of Science \& Technology, is the corresponding author of this report. He can be contacted via e-mail at jamiemeetsworld@gmail.com or by mail at No.2, West Sec. Chia-Pu Rd. Pu-tz City, Chiayi County 613, Taiwan (R.O.C.).

\section{References}

[1] Savin-Baden, M. (2000). Problem-based Learning in higher education: Untold stories. Philadelphia, PA: The Society for Research into Higher Education \& Open University Press.

[2] Evenson, D. \& Hmelo C. (2000) Problem-based learning: A research perspective on learning interactions. Mahwah, NJ: Lawrence Erlbaum Associates, Inc.

[3] Nistor, N., Schnurer, K., \& Mandl, H. (2005). Akzeptanz, Lernprozess und Lernerfolg in Virtuellen Seminaren. Wirkungsanalyse eines problem orientierten Seminarkonzepts. Research report \# 174, Ludwig-Maximilians University, Chair of Education and Educational Psychology. Retrieved from http://epub.ub.unimuenchen.de/562/1/FB_174.pdf, Munich

[4] Taradi, S., Taradi, M., Radie, K., \& Pokrajac, N. (2005). Blending problem-based learning with web technology positively impactsstudent learning outcomes in acid-base physiology. Advances in Physiology Education, 29(1), 35-39.

[5] Larson, D. K. \& Sung, C. H., (2009). Comparing student's performance: Online versus blended versus face-toface. Journal of Asynchronous Learning Networks, 13(1), 31-42.

[6] Barrow, E. J. (2002). An evaluation of problem-based learning in a nursing theory and practice module. Nurse Education in Practice, 2(1), 55-62. doi:10.1054/nepr.2002.0043

[7] Hmelo-Silver, C. E. (2004). Problem-based learning: what and how do students learn? Educational Psychology Review, 16(3), 235-266.

[8] Zimmerman, B. J. (2000). Attaining self-regulation: A social cognitive perspective. In M. Boekaerts, P. R. Pintrich, \& M. Zeidner (Eds.), Handbook of self-regulation (pp. 13-39). San Diego, CA: Academic Press.

[9] Zimmerman, B. J. (1995). Self-regulation involves more than metacognition: A social cognitive perspective. Educational Psychologist, 30(4), 217-221.

[10] Pintrich, P. R. \& De Groot E. (1990). Motivational and self-regulated learning components of classroom academic performance. Journal of Educational Psychology, 82(1), 33-50.

[11] Pape, S. J. \& Wang, C. (2003). Middle school children's strategic behavior: Classification and relation to academic achievement and mathematical problem-solving, Instructional Science, 31, 419-449.

[12] Yumusak, N., Sungur, S., \& Çakıroglu, J. (2007). Turkish high school students' biologyachievement in relation to academic self-regulation. Educational Research and Evaluation, 13(1), 53-69. 
[13] Baumeister, R. F. \& Vohs, K. D. (2007). Self-regulation, ego depletion, and motivation. Social and Personality Psychology Compass, 1(1), 115-128.doi:10.1111/j.1751-9004.2007.00001.x

[14] Garcia, T., McKeachie, W. J., Pintrich, P. R., \& Smith, D. A. (1991). A manual for the use of the Motivated Strategies for Learning Questionnaire (Tech. Rep. No. 91-B-004). Ann Arbor, MI : The University of Michigan, School of Education.

[15] Donnelly, R. (2006). Blended problem-based learning for teacher education: Lessons learnt. Journal of Learning, Media and Technology, 31, (2), 93-116.

[16] O'Loughlin, E. F. M. \& Osterlind, S. J. (2007, January 8). Blended assessment in small to medium-sized classes. Learning Solutions Magazine. Retrieved from http://www.learningsolutionsmag.com/articles/197/blendedassessment-in-small-to-medium-sized-classes

[17] Schwartz, D. L. \& Bransford, J. D. (1998). A time for telling. Cognition \& Instruction, 16, 475-522.

[18] Derry, S. J., Siegel, M., Stampen, J., \& the STEP Research Group (2002). The STEP system for collaborative casebased teacher education: Design, evaluation and future directions. Proceedings of computer support for collaborative learning (CSCL) (pp. 209-216). Mahwah, NJ: Erlbaum.

[19] Downing, K., Kwong, T., Chan, S., Lam, T., \& Downing, W. (2009). Problem-based learning and the development of metacognition. Higher Education, 57(5), 609-621. doi:10.1007/s10734-008-9165-x

[20] Aycock, A., Garnham, C., \& Kaleta, R. (2002). Lessons learned from the hybrid course project. Teaching with Technology Today,_8(6), 22-33.

[21] Fanter, Amy. (2002) Hybrid education: The future of instructional models. World Wide Learn. Retrieved from http://www.worldwidelearn.com/education-articles/hybrid-education.html

[22] Dziuban, C.D., Hartman, J.L., \& Moskal, P.D. (2004). Blended learning. EDUCAUSE Center for Applied Research Bulletin, 7, 112.

[23] Garrison, D. R. \& Kanuka, H. (2004). Blended learning: Uncovering its transformative potential in higher education. The Internet and Higher Education, 7(2), 95-105. doi:10.1016/j.iheduc.2004.02.001

[24] Williams, B. (2009). Do undergraduate paramedic students embrace case based learning using a blended teaching approach? A 3-year review. Australasian Journal of Educational Technology, 25(3), 421-439.

[25] U.S. Department of Education (2009). Evaluation of evidence-based practices in online learning: A meta-analysis and review of online learning studies. Retrieved from http://www2.ed.gov/rschstat/eval/tech/evidence-basedpractices/finalreport.pdf [December 2009]

[26] Walker, A. \& Leary, H. (2009). A problem based learning meta-analysis: Differences across problem types, implementation types, disciplines, and assessment levels. Interdisciplinary Journal of Problem-Based Learning, 2(1), 12-43.

[27] Benson, J. (1998). Test review of the Motivated Strategies for Learning Questionnaire. In J. C. Impara \& B. S. Plake (Eds.), The thirteenth mental measurements yearbook. Retrieved from the Buros Institute's Test Reviews Online website: http://www.unl.edu/buros

[28] Pintrich, P. R., Smith D. A. F., Garcia T., \& McKeachie W. J. (1993). Reliability and predictive validity of the motivated strategies for learning questionnaire (MSLQ). Educational and Psychological Measurement, 53, 801-803.

[29] Joreskog, K. G. \& Sorbom, D. (1986). LISREL VI: Analysis of linear structural relationships by maximum likelihood, instrumental variables, and least squares methods. Mooresville, IN: Scientific Software.Baumeister, R. \& Vohs, K. (2004). Handbook of Self-Regulation: Research, Theory, and Applications. New York, NY: The Guilford Press.

[30] Garcia, T. \& Pintrich, P. (1995, April 18-22). Assessing students' motivation and learning strategies: The motivation strategies learning questionnaire. Paper presented at the Annual Meeting of the American Educational Research Association, San Francisco, CA.

[31] Cruickshank, B.J. \& Olander, J. (2002). Can problem-based instruction stimulate higher-order thinking? Journal of College Science Teaching, 31, 374-377.

[32] Goodnough, K. (2005). Issues in modified problem-based learning: A self-study in pre-service science-teacher education. Canadian Journal of Science, Mathematics, \& Technology Education, 5(3), 289-306.

[33] Pintrich, P. R. \& Garcia, T. (1991). Student goal orientation and self-regulation in the college classroom. In M.L. Maehr \& P.R. Pintrich (Eds.), Advances in motivation and achievement: Goals and self-regulatory processes, (Vol.7, pp. 371-402). Greenwich, CT: JAI Press.

[34] Baumeister, R. \& Vohs, K. (2004). Handbook of Self-Regulation: Research, Theory, and Applications. New York, NY: The Guilford Press.] 
[35] Means, B., Toyama,Y., Murphy. R., Bakia, M. \& Jones, K. (2009). Evaluation of evidence -based practices in online learning: A meta-analysis and review of online-learning studies.

[36] Zhang, K. (2004). Effects of peer-controlled or externally structured and moderated online collaboration on group problem solving processes and related individual attitudes in well-structured and ill-structured small group problem solving in a hybrid course (Doctoral dissertation, The Pennsylvania State University, 2004.)

[37] Cavus, N. (2007). Assessing the Success Rate of Students Using a Learning Management System Together with a Collaborative Toll in Web-based Teaching of Programming Languages. Journal of Educational Computing Research. Retrieved from http://www.pcmag.com/encyclopedia_term/0,2542,t=learning+management+system\&i=46205,00.asp on December 12, 2009

[38] Dinov, I. D. (2008). Integrated multidisciplinary and technology-enhanced science education: The next frontier. Journal of Online Learning and Teaching, 4, 84-93.

[39] Karabenick, S. (1998). Strategic help seeking: Implications for learning and teaching. Mahwah, NJ: Erlbaum.

[40] Kitsanta, A. \& Chow, A. (2007). College students' perceived threat and preference for seeking help in traditional, distributed, and distance learning environments. Computers \& Education, 48, 383-395.

[41] Keefer, J. \& Karabenick, S., (1998). Help seeking in the information age. In S.A. Karabenick (Ed.), Strategic help seeking: Implications for learning and teaching (pp. 219-250). Mahwah, NJ: Erlbaum. 